\title{
Electrochemical Degradation Mechanism of a Cermet Anode for Aluminum Production
}

\author{
P. Meyer ${ }^{1}$, L. Massot ${ }^{1}$, M. Gibilaro¹, S. Bouvet ${ }^{2}$, V. Laurent ${ }^{2}$, A. Marmottant ${ }^{2}$, P. Chamelot ${ }^{1}$ \\ ${ }^{1}$ Laboratoire de Génie Chimique, Université de Toulouse, UPS-CNRS-INPT, Toulouse Cedex, France \\ ${ }^{2}$ Rio Tinto, Aluval, Voreppe Cedex, France \\ Email: ^massot@chimie.ups-tlse.fr
}

How to cite this paper: Meyer, P., Massot, L., Gibilaro, M., Bouvet, S., Laurent, V., Marmottant, A. and Chamelot, P. (2019) Electrochemical Degradation Mechanism of a Cermet Anode for Aluminum Production. Materials Sciences and Applications, 10, 614-629.

https://doi.org/10.4236/msa.2019.109044

Received: August 27, 2019

Accepted: September 16, 2019

Published: September 19, 2019

Copyright (c) 2019 by author(s) and Scientific Research Publishing Inc. This work is licensed under the Creative Commons Attribution International License (CC BY 4.0).

http://creativecommons.org/licenses/by/4.0/

\begin{abstract}
Tests on $\left(\mathrm{Ni}_{x} \mathrm{Fe}_{y} \mathrm{O}_{4}-\mathrm{Ni}_{1-x} \mathrm{Fe}_{x} \mathrm{O}\right) /\left(\mathrm{Cu}_{x} \mathrm{Ni}_{y} \mathrm{Fe}_{z}\right)$ cermets, considered as promising anode for the aluminium production, were performed under electrolysis at $0.8 \mathrm{~A} \cdot \mathrm{cm}^{-2}$ in molten mixture of cryolite at $960^{\circ} \mathrm{C}$. In order to predict phase compositions, a thermodynamic study was performed and experimentally verified by SEM-EDS analysis. The metallic phase oxidation leads to the formation of different phases such as $\mathrm{FeF}_{2}, \mathrm{Ni}_{0.90} \mathrm{Fe}_{0.10} \mathrm{O}, \mathrm{NiF}_{2}$ and $\mathrm{Cu}_{2} \mathrm{O}$ phases, while $\mathrm{Ni}_{\mathrm{x}} \mathrm{Fe}_{3-\mathrm{x}} \mathrm{O}_{4}$ spinel is continuously enriched up to $x=0.90$, the thermodynamically stable nickel composition. When the cermet material is fully oxidized, metallic and oxide phases are converted into soluble or non-conductive phases, leading to the end of anode service life.
\end{abstract}

\section{Keywords}

Metal/Oxide Electrode, Aluminium Electrolysis, Oxidation Reaction Mechanism

\section{Introduction}

Hall-Héroult process produces aluminium by alumina electrolysis $\left(\mathrm{Al}_{2} \mathrm{O}_{3}\right)$ in a molten mixture of cryolite at high temperature $\left(960^{\circ} \mathrm{C}\right)[1]$ :

$$
2 \mathrm{Al}_{2} \mathrm{O}_{3(\text { sol })}+3 \mathrm{C} \rightarrow 4 \mathrm{Al}_{(1)}+3 \mathrm{CO}_{2(\mathrm{~g})}
$$

Aluminum metal is obtained at the cathode and oxygen ions react with a reactive carbon anode to produce carbon dioxide. The electrolyte is composed of $\mathrm{Na}_{3} \mathrm{AlF}_{6}-\mathrm{AlF}_{3}-\mathrm{CaF}_{2}$ and $\mathrm{Al}_{2} \mathrm{O}_{3}$ according to a $\mathrm{NaF} / \mathrm{AlF}_{3}$ molar ratio of 2.2 (called cryolitic ratio $\mathrm{CR}$ ).

One of the key challenges for the aluminum industry is to replace $\mathrm{CO}_{2}$ by $\mathrm{O}_{2}$ release on an inert anode. The basic requirements for an inert anode are listed 
below [2]:

- High thermo-mechanical properties (shock and thermal gradient resistances).

- High electrical conductivity $\left(>80 \mathrm{~S} \cdot \mathrm{cm}^{-1}\right)$.

- High stability to oxidation at high temperature.

- Consumption rate lower than $1 \mathrm{~cm} /$ year for $0.8 \mathrm{~A} \cdot \mathrm{cm}^{-2}$.

To fulfill these conditions, three types of inert anode for aluminum electrolysis have been examined up to now:

- Metals or alloys [3] [4] [5], for their good ductility, conductivity and thermal chock resistance. However, metals are highly degraded under oxidation and thus cannot be used as anode (eg: Fe, Ni or Co metals [3]).

- Ceramics [6] [7], for their excellent oxidation resistance, but are generally brittle and have a low conductivity incompatible with an electrolysis process (eg. spinel $\mathrm{Ni}_{x} \mathrm{Fe}_{3-x} \mathrm{O}_{4}$ ).

- Cermets (CERamic-METals) [8] [9], made of ceramics (monoxide MO, nickel ferrite $\mathrm{Ni}_{\mathrm{x}} \mathrm{Fe}_{3-\mathrm{x}} \mathrm{O}_{4}$ ) and metal, combining the advantages of both materials. The first patents on cermet anodes have been published by Aluminum Company of America (ALCOA) in the 80's [10] [11].

ALCOA studied cermets composed of copper as metallic phase and a mixture of $\mathrm{NiFe}_{2} \mathrm{O}_{4}$ and $\mathrm{NiO}$ [12] [13]. Anodes were tested in cryolite at $0.8 \mathrm{~A} \cdot \mathrm{cm}^{-2}$ at $970^{\circ} \mathrm{C}$ and analyzed by SEM-EDS. The $83 \mathrm{wt} \%\left(80 \mathrm{NiFe}_{2} \mathrm{O}_{4}-20 \mathrm{NiO}\right) / 17 \mathrm{wt} \% \mathrm{Cu}$ composition presented the best resistance to polarisation.

Studies by Lai et al. [14] on cermets composed of $83\left(90 \mathrm{NiFe}_{2} \mathrm{O}_{4}-10 \mathrm{NiO}\right) / 17 \mathrm{Ni}$ concern the degradation mechanism at $960^{\circ} \mathrm{C}$ under electrolysis at $0.8 \mathrm{~A} \cdot \mathrm{cm}^{-2}$ in molten cryolite (saturated in $\mathrm{Al}_{2} \mathrm{O}_{3}$ ). The authors observed preferential oxidation of metallic $\mathrm{Ni}$, leading to porosity in the structure, and electrolyte penetration along the grain boundaries. The authors also pointed out a chemical dissolution of the spinel phase and a reaction between $\mathrm{NiO}$ and $\mathrm{AlF}_{3}$ to form $\mathrm{NiF}_{2}$ and $\mathrm{Al}$ metal. Tian et al. [15] completed this work by varying the metallic Ni content from 0 to $20 \mathrm{wt} \%$ at $970^{\circ} \mathrm{C}$ under polarisation at $1 \mathrm{~A} \cdot \mathrm{cm}^{-2}$ and $\mathrm{CR}=2.3(4 \mathrm{wt} \%$ $\mathrm{Al}_{2} \mathrm{O}_{3}$ ). According to their results, cermet composed of $5 \mathrm{wt} \%$ of metallic Ni presented the best resistance to degradation and the best electrical conductivity under polarisation.

Liu et al. [16] investigated a $\mathrm{Cu}-\mathrm{Ni}$ mixture as metallic phase in the $83\left(90 \mathrm{NiFe}_{2} \mathrm{O}_{4}-10 \mathrm{NiO}\right) / 17(\mathrm{Cu}-10 \mathrm{Ni})$ material. Studies were performed in molten cryolite at $960^{\circ} \mathrm{C}$, under electrolysis at $1 \mathrm{~A} \cdot \mathrm{cm}^{-2}$ and $\mathrm{CR}=2.3$, saturated in $\mathrm{Al}_{2} \mathrm{O}_{3}$. A dense $\mathrm{NiFe}_{2} \mathrm{O}_{4}$ layer was formed at the anode surface, whose thickness increased during the electrolysis process. A higher oxidation rate of $\mathrm{Cu}$ compared to $\mathrm{Ni}$ was observed in the cermet. By comparing the microstructure of $90\left(90 \mathrm{NiFe}_{2} \mathrm{O}_{4}-10 \mathrm{NiO}\right) / 10 \mathrm{Cu}$ and $90\left(90 \mathrm{NiFe}_{2} \mathrm{O}_{4}-10 \mathrm{NiO}\right) / 10(\mathrm{Ni}-\mathrm{Cu})$ cermets after electrolysis, He et al. [17] suggested, in agreement with Lai et al. [12], a preferential oxidation of the metallic phase and an increase of the porosity. A dense layer was formed at the salt/electrode interface by reaction between $\mathrm{NiFe}_{2} \mathrm{O}_{4}$ and $\mathrm{Al}_{2} \mathrm{O}_{3}$ to form $\mathrm{NiAl}_{2} \mathrm{O}_{4}$ and $\mathrm{FeAl}_{2} \mathrm{O}_{4}$. The authors suggested that this 
layer acted as a protective barrier, limiting the cermet oxidation, and concluded that the cermet composition with metallic $\mathrm{Ni}$ is the most promising inert anode.

Tests were also performed on $\left(90 \mathrm{NiFe}_{2} \mathrm{O}_{4}-10 \mathrm{NiO}\right) /(\mathrm{Ni}-\mathrm{Cu})$ at $0.95 \mathrm{~A} \cdot \mathrm{cm}^{-2}$ in $\mathrm{Na}_{3} \mathrm{AlF}_{6}-\mathrm{K}_{3} \mathrm{AlF}_{6}-\mathrm{AlF}_{3}-\mathrm{Al}_{2} \mathrm{O}_{3}$ at $900^{\circ} \mathrm{C}$ by Tian et al. [18] but anodes were still highly deteriorated. A dense layer composed of $\mathrm{FeAl}_{2} \mathrm{O}_{4}, \mathrm{NiAl}_{2} \mathrm{O}_{4}$ and $\mathrm{CuAl}_{2} \mathrm{O}_{4}$ was formed $(150 \mu \mathrm{m})$ at the salt/electrode interface, and is supposed to protect the initial cermet material. More recently, Meyer et al. [19] observed that $\mathrm{FeAl}_{2} \mathrm{O}_{4}$ is rapidly dissolved in molten cryolite.

Despite intensive investigations, no satisfactory inert anode material composition has been found yet and no global degradation mechanism of cermet under polarisation is proposed.

A cermet developed in house (described in $\$ 2 . \mathrm{d}$ ) was tested under galvanostatic electrolysis at $0.8 \mathrm{~A} \cdot \mathrm{cm}^{-2}$ in $\mathrm{Na}_{3} \mathrm{AlF}_{6}-\mathrm{AlF}_{3}-\mathrm{CaF}_{2}-\mathrm{Al}_{2} \mathrm{O}_{3}$ at $960^{\circ} \mathrm{C}$ for different durations under $\mathrm{Ar}$ atmosphere. Anodes were analyzed by Scanning Electron Microscopy (SEM), coupled with the energy-dispersive X-ray spectroscopy (EDS), to determine the microstructure compositions. From these analyses, an electrochemical degradation mechanism of the cermet is proposed and validated by thermodynamic calculations using Factsage 7.1 software.

\section{Experimental}

\subsection{The Cell}

The cell was a vitreous carbon crucible placed in a cylindrical vessel made of refractory steel and closed by a stainless steel lid cooled by circulating water. The inside part of the walls was protected against fluoride vapors by a graphite liner. The experiments were performed under an inert argon atmosphere (4.5 grade), previously dehydrated. The cell was heated using a programmable furnace and the temperatures were measured using a chromel-alumel thermocouple. A schematic diagram of the experimental setup has already been presented in previous article [20].

The cryolite melt is composed of $\mathrm{Na}_{3} \mathrm{AlF}_{6}$ (Carlo Erba, purity 99.99\%), with an addition of $11 \mathrm{wt} \%$ excess of $\mathrm{AlF}_{3}$ (ProChem Inc, purity 99.99\%) and $5 \mathrm{wt} \%$ of $\mathrm{CaF}_{2}$ (Apollo Scientific, purity 99.99\%), leading to a cryolitic ratio (CR) of 2.2. Alumina saturation was achieved by addition of $8 \mathrm{wt} \%$ of alumina (Alfa Aesar, purity $99 \%)$. The salt mixture was heated until $960^{\circ} \mathrm{C}$ under argon atmosphere.

\subsection{Electrodes}

A parallelepipedic shaped cermet $\left(1.25 \mathrm{~cm}^{2}\right.$ surface area) was used as working electrode. This relatively small surface area was selected to ensure its full degradation within few hours. The auxiliary electrode was a Ni plate to avoid Al metal in the salt (formation of Al-Ni alloys). The reference electrode is a molybdenum wire (Goodfellow 99.99\%, $0.5 \mathrm{~mm}$ diameter) enclosed in a boron nitride crucible (BN, AX05 grade), immersed into the bath, in contact with the solution through a $0.3 \mathrm{~mm}$ diameter hole. 


\subsection{Techniques}

The electrochemical studies and galvanostatic electrolyses were performed with an Autolab PGSTAT302N potentiostat/galvanostat controlled with the NOVA 2.1 software. The cermets were embedded in cold conductive resin and polished for surface analysis of their cross-sections. Scanning electron microscope (SEM) with a Backscattered Electron (BSE) detector observations coupled with EDS analysis were performed on a PhenomWorldXL.

\subsection{The Cermet}

Cermet was obtained by a powder metallurgy process: $\mathrm{NiFe}_{2} \mathrm{O}_{4}, \mathrm{NiO}, \mathrm{Ni}$ and $\mathrm{Cu}$ powder were mixed together with an organic binder, isostatically pressed and sintered at $1350^{\circ} \mathrm{C}$. After sintering, this cermet is composed of spinel $\left(\mathrm{Ni}_{x} \mathrm{Fe}_{3-x} \mathrm{O}_{4}\right)$, nickel iron monoxide $\left(\mathrm{Ni}_{1-x} \mathrm{Fe}_{x} \mathrm{O}\right)$ and copper-nickel-iron alloy $\left(\mathrm{Cu}_{x} \mathrm{Ni}_{y} \mathrm{Fe}_{z}\right)$. Figure 1 shows the stable phases when the partial pressure of oxygen is $10^{-10} \mathrm{~atm}$. in the ternary diagram of $\mathrm{Ni}, \mathrm{Cu}, \mathrm{Fe}$ system. The back point is the proportion of the nickel, iron and copper elements in the studied cermet; its microstructure is composed of monoxide and metal phases, included in a continuous spinel matrix, and the residual porosity is $2 \%_{\text {voll }}$.

\section{Results and Discussion}

\subsection{Thermodynamic Approach}

To predict the oxidised phase compositions, thermodynamic evaluation of Gibbs

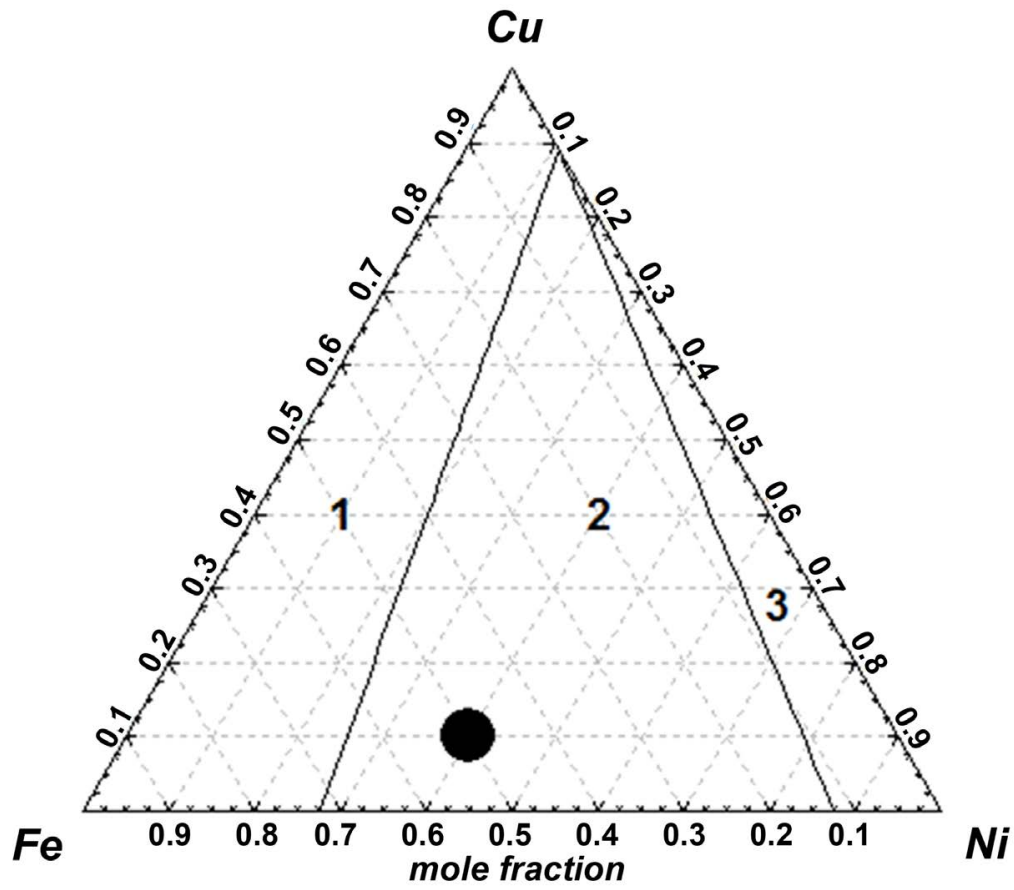

Figure 1. Ternary diagram of the $\mathrm{Ni}, \mathrm{Cu}$, Fe system $\left(\mathrm{pO}_{2}=10^{-10} \mathrm{~atm}\right)$. Zone 1: metal and spinel coexistence. Zone 2: metal, spinel and monoxide coexistence; Zone 3: metal and monoxide coexistence. 
free energies was realised with FactSage 7.1 software, with FactPS, FTOxid, SGTEa and FTHall databases. Standard states were selected as follows for the different species: the gaseous species ( $\mathrm{g}$ ) obeys the ideal gas equation at standard pressure $(P=1 \mathrm{~atm})$, the solid (s) and liquid (l) compounds are considered as pure substances. Moreover, all the calculations were performed at $960^{\circ} \mathrm{C}$.

From these values, standard potentials were calculated as follows:

$$
\Delta G^{\circ}=n F E^{\circ}
$$

- In presence of fluoride ions, $\mathrm{F}_{2(\mathrm{~g})} / \mathrm{F}^{-}$redox couple was used to express the iron oxidation as:

$$
\begin{gathered}
\mathrm{Fe}_{(\mathrm{s})}+2 \mathrm{~F}^{-} \rightarrow \mathrm{FeF}_{2(\mathrm{~s})}+2 \mathrm{e}^{-} \\
\mathrm{F}_{2(\mathrm{~g})}+2 \mathrm{e}^{-} \leftrightarrows 2 \mathrm{~F}^{-} \\
\mathrm{Fe}_{(\mathrm{s})}+\mathrm{F}_{2(\mathrm{~g})} \rightarrow \mathrm{FeF}_{2(\mathrm{~s})}
\end{gathered}
$$

Gibbs free energy was determined for Equation (4) at $960^{\circ} \mathrm{C}$ : $\Delta G=-535.81 \mathrm{~kJ} \cdot \mathrm{mol}^{-1}$.

The $\mathrm{FeF}_{2} / \mathrm{Fe}$ standard potential is equal to $E_{\left(\mathrm{FeF}_{2} / \mathrm{Fe}\right)}^{\circ}=-2.80 \mathrm{~V} \quad$ vs. $\mathrm{F}_{2(\mathrm{~g})} / \mathrm{F}^{-}$.

- In presence of oxide ions, $\mathrm{O}_{2(\mathrm{~g})} / \mathrm{O}^{2-}$ redox couple was selected and the iron oxidation reaction is:

$$
\begin{gathered}
\mathrm{Fe}_{(\mathrm{s})}+\mathrm{O}^{2-} \rightarrow \mathrm{FeO}_{(\mathrm{s})}+2 \mathrm{e}^{-} \\
1 / 2 \mathrm{O}_{2(\mathrm{~g})}+2 \mathrm{e}^{-} \leftrightarrows \mathrm{O}^{2-} \\
\mathrm{Fe}_{(\mathrm{s})}+\frac{1}{2} \mathrm{O}_{2(\mathrm{~g})} \rightarrow \mathrm{FeO}_{(\mathrm{s})}
\end{gathered}
$$

where $\mathrm{O}^{2-}$ represents all the fluoroaluminates ions $\left[\mathrm{Al}_{x} \mathrm{O}_{y} \mathrm{~F}_{z}\right]^{3 x-2 y-z}$ that can be oxidized to produce dioxygen [21] [22] [23].

The Gibbs free energy determined by FactSage for Equation (7) at $960^{\circ} \mathrm{C}$ is $\Delta G^{\circ}=-184.16 \mathrm{~kJ} \cdot \mathrm{mol}^{-1}$, corresponding to $E_{(\mathrm{FeO} / \mathrm{Fe})}^{\circ}=-0.88 \mathrm{~V} \quad$ vs. $\mathrm{O}_{2(\mathrm{~g})} / \mathrm{O}^{2-}$.

To compare the fluoride and the oxide species standard potentials, the same reference potential is needed: $\mathrm{AlF}_{3} / \mathrm{Al}(\mathrm{l})$ redox couple was chosen; the reference potential change is explained elsewhere [24].

The study was realised with the constitutive elements of the anode $(\mathrm{Cu}, \mathrm{Ni}, \mathrm{Fe})$ considered as pure elements and the results are gathered in Figure 2.

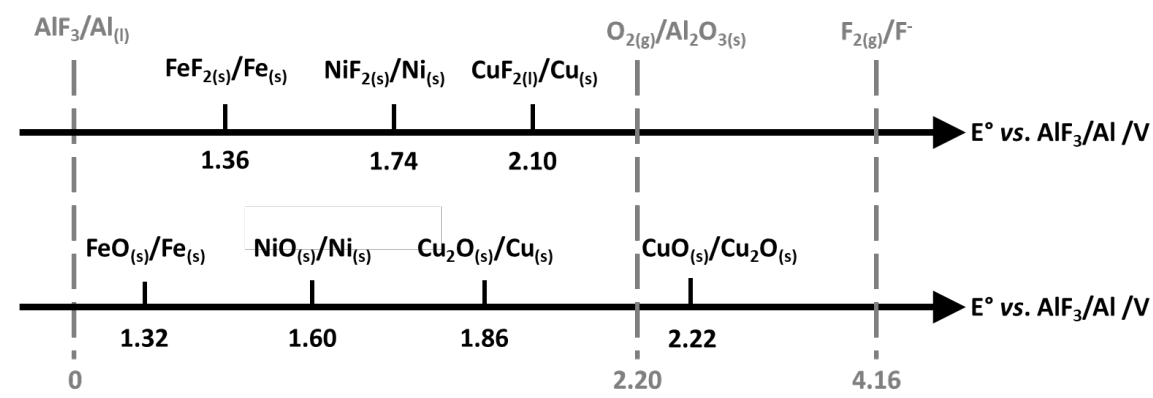

Figure 2. Standard potentials scales determined at $960^{\circ} \mathrm{C}$. 
From these scales, metallic iron is the first element to be oxidized into $\mathrm{FeO}$ and $\mathrm{FeF}_{2}$, depending on $\mathrm{O}^{2-}$ content. Then, nickel is oxidized into $\mathrm{NiO}$ or $\mathrm{NiF}_{2}$ and copper into $\mathrm{Cu}_{2} \mathrm{O}, \mathrm{CuF}_{2}$ and $\mathrm{CuO}$. All these oxide/fluoride formations were confronted to micrographic analyses of the anode after electrolysis. In this work, the potentials will be referenced to $\mathrm{AlF}_{3} / \mathrm{Al}$ redox couple.

\subsection{Experimental Anodic Potential during the Electrolysis Process at $0.8 \mathrm{~A} \cdot \mathrm{cm}^{-2}$}

On the cermet anode, oxygen is produced; to characterise the material oxidation, a linear voltammogram was plotted at $50 \mathrm{mV} \cdot \mathrm{s}^{-1}$ on the cermet and on gold electrode, in a CR 2.2 bath containing $5 \mathrm{wt} \%$ of $\mathrm{CaF}_{2}$ saturated in alumina at $960^{\circ} \mathrm{C}$ (Figure 3).

On the $j$ vs. $E$ curve, two zones are observed, meaning that at least two reactions take place. To identify the $\mathrm{O}_{2}$ evolution, a gold electrode was selected as only $\mathrm{O}_{2}$ is formed [25]. The linear voltammetry superimposition shows that the second zone (from $2 \mathrm{~V} v s$. ref) corresponds to $\mathrm{O}_{2}$ evolution and the first zone can be attributed to the cermet material oxidation (between $1.55 \mathrm{~V} v s$. ref and 2 V vs. ref).

In our experimental conditions $\left(j=0.8 \mathrm{~A} \cdot \mathrm{cm}^{-2}\right)$, the anode potential during the electrolysis is around $2.8 \mathrm{~V} v s$. ref, meaning that both $\mathrm{O}_{2}$ evolution and material oxidation take place: the next paragraph deals with the investigation of the material electrochemical degradation.

\subsection{Determination of the Electrochemical Degradation Mechanism}

The approach used to determine the material degradation steps was:

- Electrolyses at $0.8 \mathrm{~A} . \mathrm{cm}^{-2}$ for different polarization durations.

- SEM analysis of the anode cross-section to observe the changes of oxide and metallic phases.

- EDS analysis to determine their compositions.

As the cermet degradation state is function of its geometrical dimensions, the

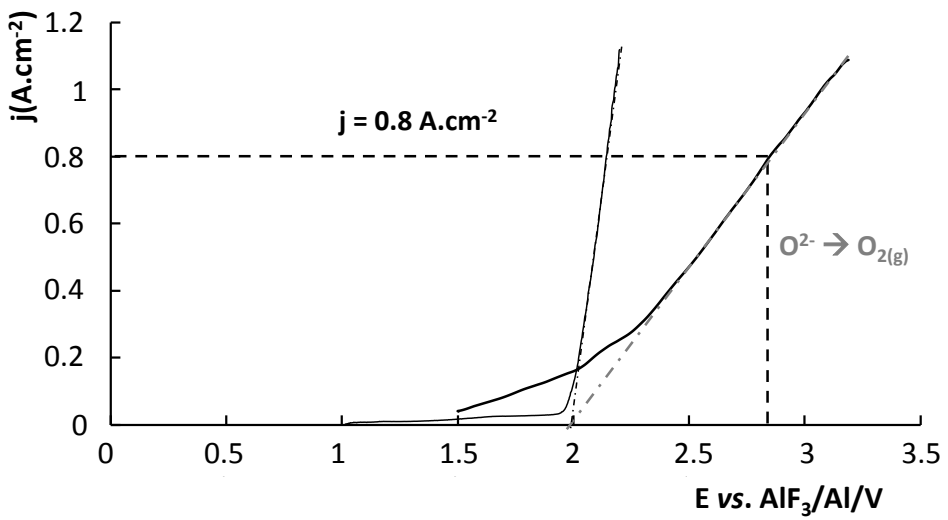

Figure 3. Linear voltammograms $\left(\mathrm{vb}=0.050 \mathrm{~V} \cdot \mathrm{s}^{-1}\right)$ plotted on gold electrode (thin line) and cermet (bold) in cryolitic bath $\left(\mathrm{CR}=2.2,5 \mathrm{wt} \% \mathrm{CaF}_{2}\right.$, saturated in $\left.\mathrm{Al}_{2} \mathrm{O}_{3}, \mathrm{~T}=960^{\circ} \mathrm{C}\right)$. 
electrolysis time was converted into a degradation progress $(\lambda)$; for $\lambda=1$, the CERMET is fully oxidised, and corresponds to the anode service life.

The global cermet electrolysis curve $E=f(\lambda)$, corresponding to the anode end of life $(\lambda=1)$, is shown in Figure 4 .

This curve is divided into three zones:

- In zone $1(\mathrm{Z} 1)$, the potential is stable and corresponds to the potential previously measured by linear voltammetry $\left(E=2.8 \mathrm{~V} v s . \mathrm{AlF}_{3} / \mathrm{Al}\right)$.

- In zone 2 (Z2), a significant increase of the potential is observed.

- In zone $3(\mathrm{Z3})$, the potential strongly increases up to $10 \mathrm{~V} v s . \mathrm{AlF}_{3} / \mathrm{Al}$.

A progressive increase of the anode potential is then observed with the electrolysis duration. To investigate the electrochemical degradation mechanism, electrolyses were performed in the different zones and results are detailed below.

\subsubsection{Zone 1: Formation of Monoxide and Fluoride Phases}

Figure 5 shows the SEM micrographs of the cermet interface after different degradation progresses $\lambda=6.25 \%, 12.5 \%$ and $25 \%$.

These micrographs show an important decrease of the metallic phase amount with the electrolysis duration: at the anode/electrolyte interface $(100 \mu \mathrm{m})$, only $30 \%$ of the initial metal remains in the structure for $\lambda=25 \%$. The metallic phase is then continuously oxidized and leads to:

- $\mathrm{FeF}_{2}$ : this new phase is detected in contact with metallic grains up to $120 \mu \mathrm{m}$ depth for $\lambda=6.25 \%$, (Figure 5(a)). Its formation can result from the oxidation of iron metal in presence of fluoride ions according to the reaction:

$$
\mathrm{Fe}+2 \mathrm{~F}^{-} \rightarrow \mathrm{FeF}_{2}+2 \mathrm{e}^{-}
$$

This result is in agreement with the thermodynamic approach (Figure 2), where the iron metal is the first element to be oxidized.

Moreover, at $45 \mu \mathrm{m}$ from the anode/electrolyte interface (Figure 5(c)), the detected fluoride phases contain both $\mathrm{FeF}_{2}$ and $\mathrm{NiF}_{2} . \mathrm{NiF}_{2}$ can be obtained by oxidation of nickel metal with fluoride ions, according to the following reaction:

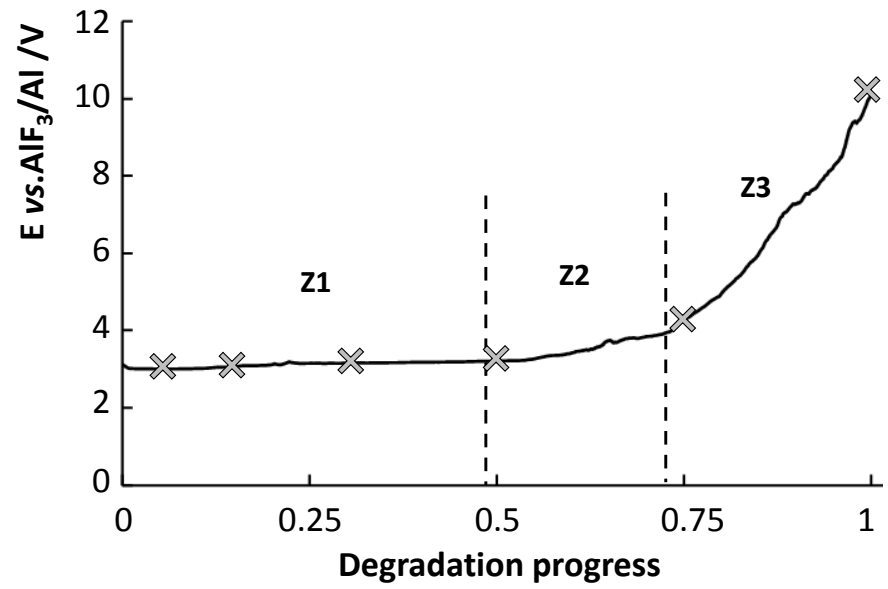

Figure 4. Variation of anode potential vs the degradation progress for electrolysis at 0.8 A $\cdot \mathrm{cm}^{-2}$ in a $\mathrm{CR}=2.2$ bath saturated in alumina with $5 \%$ wt of $\mathrm{CaF}_{2}$ at $960^{\circ} \mathrm{C}$. X: tested durations. 


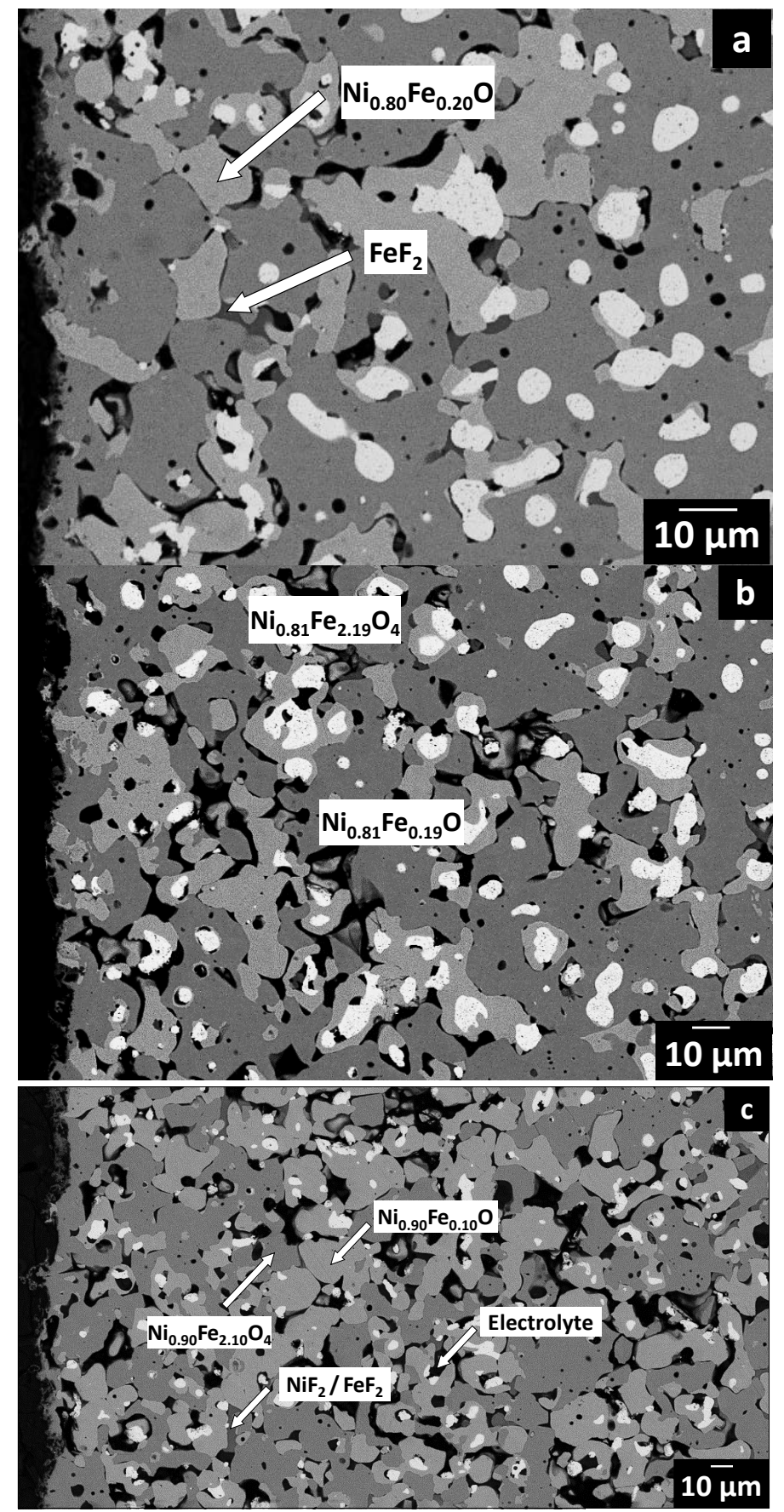

Figure 5. SEM micrographs of the cermet interface after electrolysis at $0.8 \mathrm{~A} \cdot \mathrm{cm}^{-2}$ in a CR $=2.2$ bath, saturated in $\mathrm{Al}_{2} \mathrm{O}_{3}$ with $5 \%$ wt of $\mathrm{CaF}_{2}$ at $960^{\circ} \mathrm{C}$ : (a) $\lambda=6.25 \%$ (b) $\lambda=12.5 \%$ (c) $\lambda=25 \%$.

$$
\mathrm{Ni}_{(\mathrm{s})}+2 \mathrm{~F}^{-} \rightarrow \mathrm{NiF}_{2(\mathrm{~s})}+2 \mathrm{e}^{-}
$$

However, at the anode/electrolyte interface, $\mathrm{FeF}_{2}$ and $\mathrm{NiF}_{2}$ are never detected: it might be due to their dissolution in the electrolyte. $\mathrm{FeF}_{2}$ and $\mathrm{NiF}_{2}$ dissolution generates an additional porosity and therefore accelerates the electrolyte penetration into the cermet. 
From these observations, oxide phases are then formed next to the salt interface whereas fluoride phase are detected in the bulk. However, micrographs clearly show that their formation front moves inwards with the anode degradation progress, as presented in Table 1 where the degradation front has been measured for different degradation progress.

- $\mathrm{Ni}_{0.8} \mathrm{Fe}_{0.2} \mathrm{O}$ : this monoxide is observed close to the electrolyte.

According to the thermodynamic scales, in presence of oxide ions, iron and nickel can be oxidized into $\mathrm{FeO}$ and $\mathrm{NiO}$. However, a mixture iron and nickel monoxide is detected by EDS, so a two-step formation mechanism is proposed:

1) Metallic iron in contact with the electrolyte is oxidized into $\mathrm{FeO}$ :

$$
\mathrm{Fe}+\mathrm{O}^{2-} \rightarrow \mathrm{FeO}+2 \mathrm{e}^{-}
$$

2) $\mathrm{FeO}$ is then dissolved into $\mathrm{NiO}$, formed by oxidation of metallic nickel, according to the following reaction:

$$
0.80 \mathrm{Ni}+0.20 \mathrm{FeO}+0.80 \mathrm{O}^{2-} \rightarrow \mathrm{Ni}_{0.80} \mathrm{Fe}_{0.20} \mathrm{O}+1.60 \mathrm{e}^{-}
$$

For $\lambda=25 \%$, (Figure $5(\mathrm{c})$ ), only one monoxide composition is detected with $x=0.9$ nickel amount. This oxide composition is then the most stable and the Equation (9) becomes:

$$
0.90 \mathrm{Ni}+0.10 \mathrm{FeO}+0.90 \mathrm{O}^{2-} \rightarrow \mathrm{Ni}_{0.90} \mathrm{Fe}_{0.10} \mathrm{O}+1.80 \mathrm{e}^{-}
$$

- The $\mathrm{Ni}_{x} \mathrm{Fe}_{3-x} \mathrm{O}_{4}$ spinel phase is continuously enriched in nickel, up to a limit value of $x=0.90\left(\mathrm{Ni}_{0.90} \mathrm{Fe}_{2.10} \mathrm{O}_{4}\right)$. This final spinel composition is assumed to be the most stable one in this experimental condition [26]. To explain the nickel increase in the spinel phase, a ternary phase diagram of the $\mathrm{Ni}-\mathrm{Fe}-\mathrm{O}$ system at $960^{\circ} \mathrm{C}$ was plotted in Figure 6.

Table 1. Degradation front into the cermet for different degradation progresses.

\begin{tabular}{cccc}
\hline Duration $(\mathrm{h})$ & 0.5 & 1 & 2 \\
\hline Degradation front $(\mu \mathrm{m})$ & 180 & 250 & 590 \\
\hline
\end{tabular}

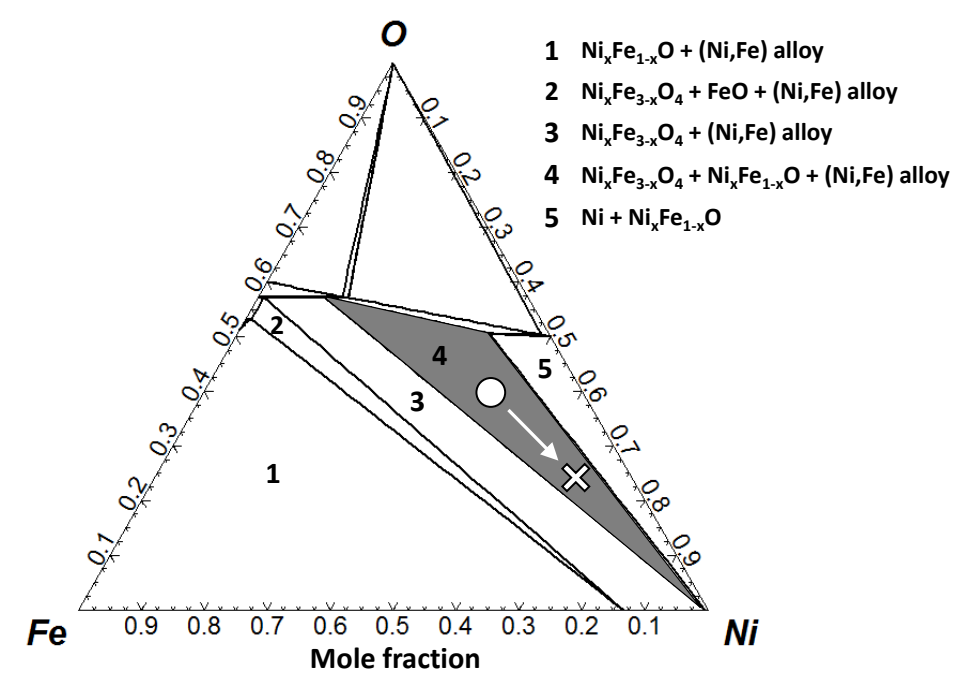

Figure 6. Phase diagram of Ni-Fe-O system at $960^{\circ} \mathrm{C}$. 
The stability zones of the material phases are represented: $\mathrm{Ni}_{x} \mathrm{Fe}_{3-x} \mathrm{O}_{4}$ spinel, $\mathrm{Ni}_{1-x} \mathrm{Fe}_{x} \mathrm{O}$ nickel iron monoxide and metallic alloy. The only part of the diagram where the three phases are in equilibrium is in the part 4 (grey zone).

The initial composition of the spinel is displayed with a circle (zone 4) and the oxidized spinel phase $\mathrm{Ni}_{0.90} \mathrm{Fe}_{2.10} \mathrm{O}_{4}$ with a cross. The $\mathrm{Ni}-\mathrm{Fe}-\mathrm{O}$ phase diagram at $960^{\circ} \mathrm{C}$ confirms the possible increase of $\mathrm{Ni}$ into the spinel phase until $x=0.90$, as observed for the monoxide phase $\left(\mathrm{Ni}_{0.90} \mathrm{Fe}_{0.10} \mathrm{O}\right)$.

The reaction producing the nickel increase can be written as:

$$
\mathrm{Ni}_{x} \mathrm{Fe}_{3-x} \mathrm{O}_{4}+y \mathrm{Ni} \rightarrow \mathrm{Ni}_{x+y} \mathrm{Fe}_{3-x-y} \mathrm{O}_{4}+y \mathrm{Fe}^{2+}+2 y \mathrm{e}^{-} \quad(x+y=0.90)
$$

This reaction releases $\mathrm{Fe}^{2+}$ which forms $\mathrm{FeF}_{2}$ according to the reaction:

$$
\mathrm{Fe}^{2+}+2 \mathrm{~F}^{-} \rightarrow \mathrm{FeF}_{2}
$$

\subsubsection{Zone 2: $\mathrm{Cu}_{2} \mathrm{O}$ Formation}

Electrolyses were then carried out in zone 2. Figure 7 represents the SEM micrographs of cermet interface (a) and core (b) at the half of the degradation $(\lambda=$ $50 \%)$.

The core of the anode (Figure 7(b)) is mainly composed of:

- Few grains of metallic phase.

- $\mathrm{Ni}_{0.90} \mathrm{Fe}_{2.10} \mathrm{O}_{4}$ spinel phase.

- $\mathrm{Ni}_{0.90} \mathrm{Fe}_{0.10} \mathrm{O}$ monoxide phase.

- A mixture of $\mathrm{NiF}_{2}$ and $\mathrm{FeF}_{2}$.

The same phases detected at the electrolyte/anode interface in zone 1 are present at the core at $\lambda=50 \%$ (Figure $7(\mathrm{~b})$ ), showing a continuous progression of the degradation front towards the core of the anode. Up to $400 \mu \mathrm{m}$ depth (Figure 7(a)), the material is only composed of oxides: $\mathrm{Ni}_{0.90} \mathrm{Fe}_{0.10} \mathrm{O}, \mathrm{Ni}_{0.90} \mathrm{Fe}_{2.10} \mathrm{O}_{4}$

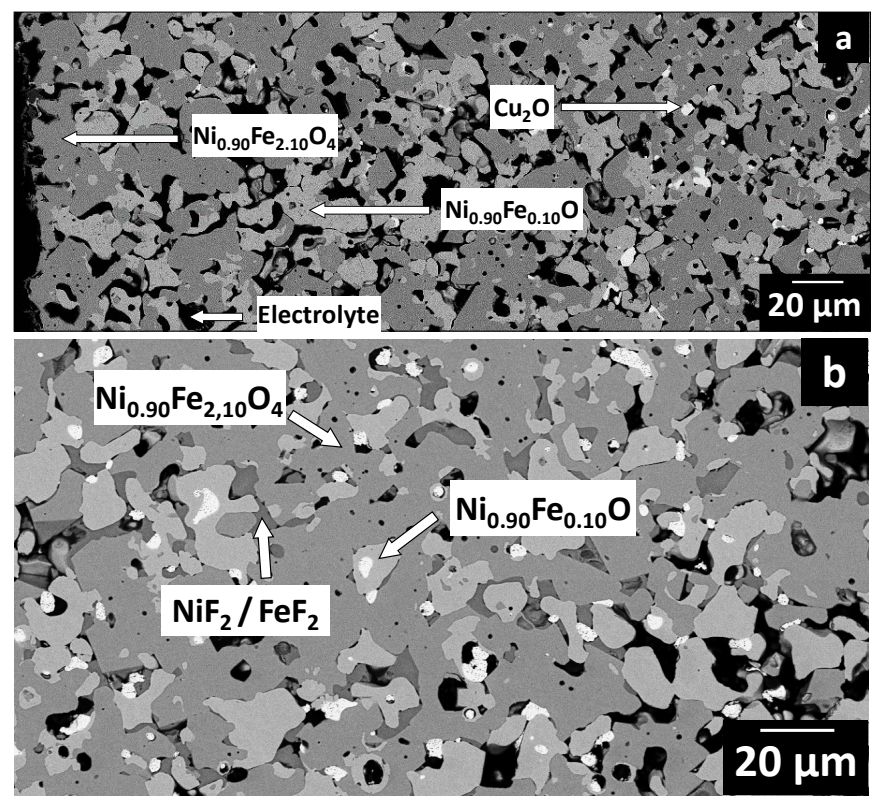

Figure 7. SEM micrographs of the cermet after electrolysis $(\lambda=50 \%)$ at $0.8 \mathrm{~A} \cdot \mathrm{cm}^{-2}$ in a $\mathrm{CR}=2.2$ bath, saturated in $\mathrm{Al}_{2} \mathrm{O}_{3}$ with $5 \mathrm{wt} \%$ of $\mathrm{CaF}_{2}$ at $960^{\circ} \mathrm{C}$ : (a) interface (b) core. 
and $\mathrm{Cu}_{2} \mathrm{O}$, formed by oxidation of metallic copper in presence of oxide ions according to the reaction:

$$
2 \mathrm{Cu}_{(\mathrm{s})}+\mathrm{O}^{2-} \rightarrow \mathrm{Cu}_{2} \mathrm{O}_{(\mathrm{s})}+2 \mathrm{e}^{-}
$$

These results are in agreement with the potential scale (Figure 2), where copper is more noble than iron and nickel. At this step, metallic iron is not present anymore and the oxide phases have reached a thermodynamically stable composition: nickel is then preferentially oxidized into $\mathrm{NiF}_{2}$, while copper is oxidized into $\mathrm{Cu}_{2} \mathrm{O}$.

The electrolyte is also present into the porosity and keeps on contributing to the dissolution of the fluoride phases.

The potential increase in zone 2 is directly correlated to the cermet composition: the metallic phase is converted into oxides and leading to porosity. The global conductivity of the anode decreases then continuously because of low conductivity oxide phase formation at $1000^{\circ} \mathrm{C}$ :

- $\mathrm{Ni}_{0.90} \mathrm{Fe}_{0.10} \mathrm{O}: 18 \mathrm{~S} \cdot \mathrm{cm}^{-1}[27]$

- $\mathrm{Ni}_{0.90} \mathrm{Fe}_{2.10} \mathrm{O}_{4}: 0.5 \mathrm{~S} \cdot \mathrm{cm}^{-1}[28]$

- $\mathrm{Cu}_{2} \mathrm{O}: 1-2 \mathrm{~S} \cdot \mathrm{cm}^{-1}[29]$

\subsubsection{Zone 3: Formation of ( $\mathrm{Ni}, \mathrm{Cu}, \mathrm{Fe}) \mathrm{O}$ Monoxide}

Electrolyses were performed in zone 3 and the SEM micrographs of the interface obtained after electrolysis at $\lambda=75 \%$ and full degradation progress are presented in Figure 8(a) and Figure 8(b).
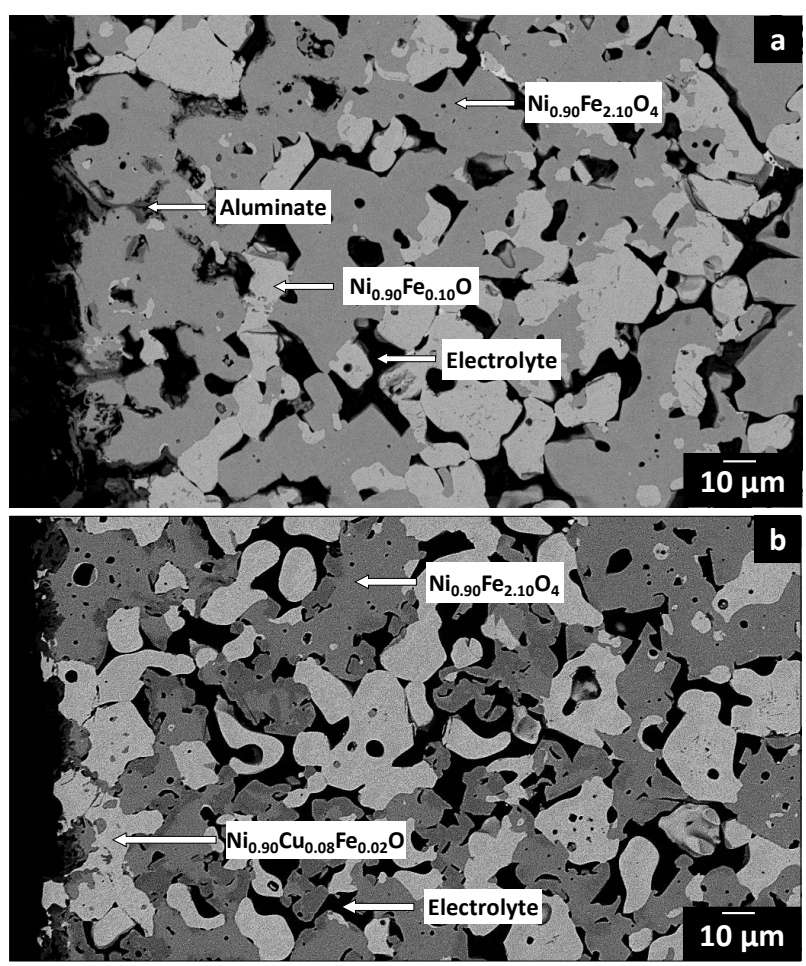

Figure 8. SEM micrographs of the cermet interface after electrolysis at $0.8 \mathrm{~A} \cdot \mathrm{cm}^{-2}$ in a CR $=2.2$ bath, saturated in $\mathrm{Al}_{2} \mathrm{O}_{3}$ with $5 \%$ wt of $\mathrm{CaF}_{2}$ at $960^{\circ} \mathrm{C}$ : (a) $\lambda=75 \%$; (b) $\lambda=100 \%$. 
At $\lambda=75 \%$, the anode is only composed of $\mathrm{Ni}_{0.90} \mathrm{Fe}_{2.10} \mathrm{O}_{4}, \mathrm{Cu}_{2} \mathrm{O}$ and electrolyte inside the material.

At $\lambda=100 \%$, the monoxide composition is $\mathrm{Ni}_{0.90} \mathrm{Cu}_{0.08} \mathrm{Fe}_{0.02} \mathrm{O}$. Copper(I) from $\mathrm{Cu}_{2} \mathrm{O}$ is oxidized into copper(II), substituting the iron(II) in the structure. As a consequence, iron(II) is released and then dissolved in the electrolyte:

$$
\begin{aligned}
& 0.04 \mathrm{Cu}_{2} \mathrm{O}_{(\mathrm{s})}+\mathrm{Ni}_{0.90} \mathrm{Fe}_{0.10} \mathrm{O}_{(\mathrm{s})}+0.16 \mathrm{~F}^{-} \\
& \rightarrow \mathrm{Ni}_{0.90} \mathrm{Cu}_{0.08} \mathrm{Fe}_{0.02} \mathrm{O}_{(\mathrm{s})}+0.08 \mathrm{FeF}_{2(\mathrm{~s})}+0.16 \mathrm{e}^{-}
\end{aligned}
$$

Figure 9(a) and Figure 9(b) represent the core of the cermet after electrolysis $\lambda=75 \%$ and $100 \%$ respectively.

In these experiments, the cermet is totally degraded:

- The metallic phase is no more detected.

- The porosity is very important, leading to a complete dissolution of fluoride phases.

- The nickel increases until $x=0.90$ in the spinel and monoxide phases confirms the formation of the most thermodynamically stable composition (\$3.2).

$\mathrm{Ni}_{0.90} \mathrm{Fe}_{2.10} \mathrm{O}_{4}$ and $\mathrm{Ni}_{0.90} \mathrm{Cu}_{0.08} \mathrm{Fe}_{0.02} \mathrm{O}$ phases are not conductive enough to ensure the current flow, meaning that the cermet has then reached its end of life.

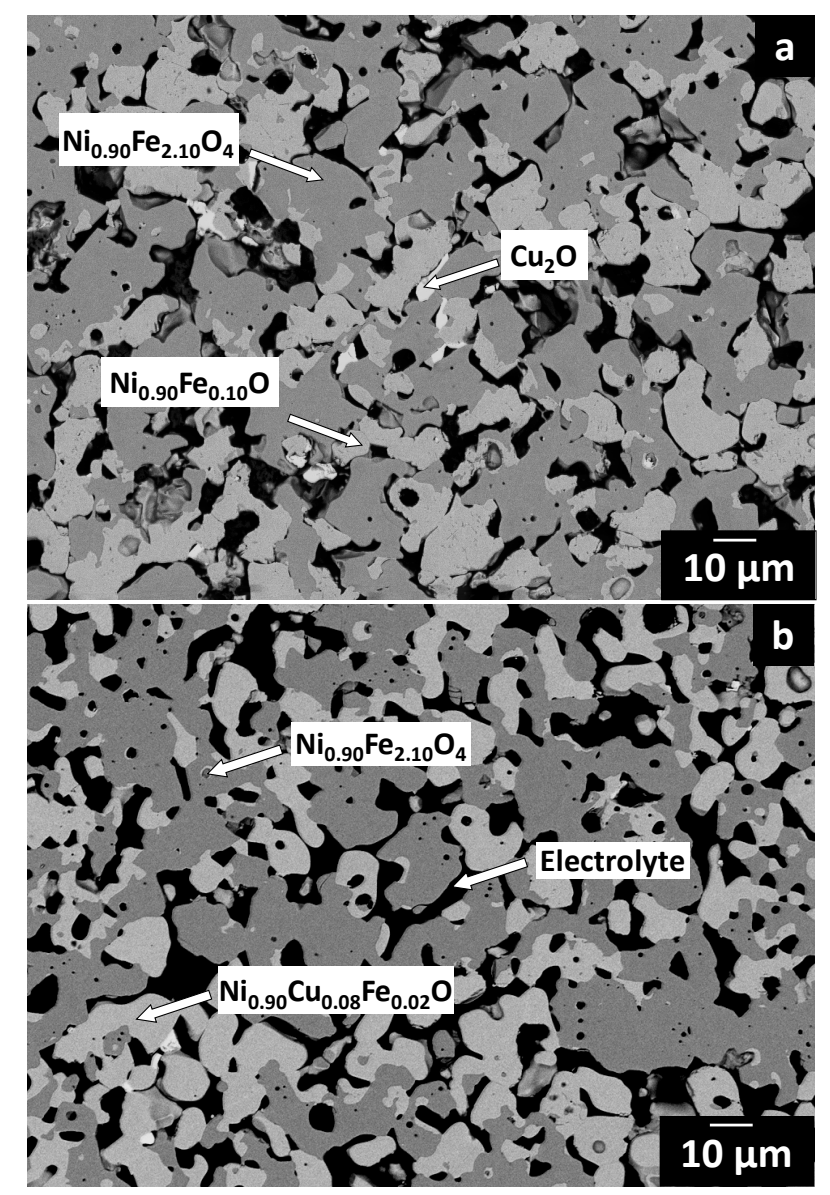

Figure 9. SEM micrographs of the core of the cermet after electrolysis at $0.8 \mathrm{~A} \cdot \mathrm{cm}^{-2}$ in a $\mathrm{CR}=2.2$ bath, saturated in $\mathrm{Al}_{2} \mathrm{O}_{3}$ with $5 \%$ wt of $\mathrm{CaF}_{2}$ at $960^{\circ} \mathrm{C}$ : (a) $\lambda=75 \%$; (b) $\lambda=100 \%$. 


\section{Conclusions}

Cermet composed of spinel, nickel monoxide and copper-nickel-iron alloy was studied as inert anode for aluminum production. Electrolysis with different durations at $0.8 \mathrm{~A} \cdot \mathrm{cm}^{-2}$ in molten mixture of cryolite at $960^{\circ} \mathrm{C}$ was undertaken and new phases formation, in addition of dioxygen evolving, was evidenced by SEM coupled with EDS analysis.

- The oxidation of metallic phase, coupling with thermodynamic calculations, showed that iron is the first element to be oxidized, into $\mathrm{FeF}_{2}$ in presence of fluoride $\mathrm{F}^{-}$and into $\mathrm{FeO}$ with $\mathrm{O}^{2-}$ from the electrolyte:

$$
\begin{aligned}
\mathrm{Fe}_{(\mathrm{s})}+2 \mathrm{~F}^{-} & \rightarrow \mathrm{FeF}_{2(\mathrm{~s})}+2 \mathrm{e}^{-} \\
\mathrm{Fe}+\mathrm{O}^{2-} & \rightarrow \mathrm{FeO}+2 \mathrm{e}^{-}
\end{aligned}
$$

- $\mathrm{NiF}_{2}$ and $\mathrm{Ni}_{0.90} \mathrm{Fe}_{0.10} \mathrm{O}$ phases are also detected, obtained from the oxidation of nickel metal with fluoride and $\mathrm{O}^{2-}$ ions, according to the following reactions:

$$
\begin{gathered}
\mathrm{Ni}_{(\mathrm{s})}+2 \mathrm{~F}^{-} \rightarrow \mathrm{NiF}_{2(\mathrm{~s})}+2 \mathrm{e}^{-} \\
0.90 \mathrm{Ni}+0.10 \mathrm{FeO}+0.90 \mathrm{O}^{2-} \rightarrow \mathrm{Ni}_{0.90} \mathrm{Fe}_{0.10} \mathrm{O}+1.80 \mathrm{e}^{-}
\end{gathered}
$$

- Bath penetration into the cermet occurred and led to the dissolution of the first fluorides formed.

- For the spinel phase, a nickel enrichment up to $x=0.90$ due to metallic nickel oxidation intervened:

$$
\mathrm{Ni}_{x} \mathrm{Fe}_{3-x} \mathrm{O}_{4}+y \mathrm{Ni} \rightarrow \mathrm{Ni}_{x+y} \mathrm{Fe}_{3-x-y} \mathrm{O}_{4}+y \mathrm{Fe}^{2+}+2 y \mathrm{e}^{-} \quad(x+y=0.9)
$$

And $\mathrm{Fe}^{2+}+2 \mathrm{~F}^{-} \rightarrow \mathrm{FeF}_{2}$

This final spinel and monoxide compositions are the most stable in our experimental conditions.

- Then $\mathrm{Cu}_{2} \mathrm{O}$ is formed by metallic copper oxidation:

$$
2 \mathrm{Cu}_{(\mathrm{s})}+\mathrm{O}^{2-} \rightarrow \mathrm{Cu}_{2} \mathrm{O}_{(\mathrm{s})}+2 \mathrm{e}^{-}
$$

- Fully oxidized, the cermet becomes non-conductive and only two oxide phases with a nickel amount of $x=0.90$ are detected:

$$
\begin{aligned}
& 0.04 \mathrm{Cu}_{2} \mathrm{O}_{(\mathrm{s})}+\mathrm{Ni}_{0.90} \mathrm{Fe}_{0.10} \mathrm{O}_{(\mathrm{s})}+0.16 \mathrm{~F}^{-} \\
& \rightarrow \mathrm{Ni}_{0.90} \mathrm{Cu}_{0.08} \mathrm{Fe}_{0.02} \mathrm{O}_{(\mathrm{s})}+0.08 \mathrm{FeF}_{2(\mathrm{~s})}+0.16 \mathrm{e}^{-}
\end{aligned}
$$

For the first time, a degradation mechanism of a cermet anode was proposed, in agreement with thermodynamic calculations. When $\mathrm{Cu}_{2} \mathrm{O}$ phase is formed (zone 2), the measured potential increases meaning that the anode is less conductive. For a long-term use, it would be interesting to increase the zone 1, where the electrolysis potential is stable, by increasing the metal proportion into the cermet: it would prevent the formation of non-conductive phases. Another possible way is the use of a low-temperature electrolyte, to slow down the oxidation phenomenon into the cermet. 


\section{Acknowledgements}

The authors express their thanks to the French Research National Agency ANR-13-RMNP-0012 for their financial support for this research.

\section{Conflicts of Interest}

The authors declare no conflicts of interest regarding the publication of this paper.

\section{References}

[1] Charles-M. (1889) Hall. US Patent No. 400766.

[2] Pawlek, R.P. (2002) Inert Anodes: An Update. In: Grandfield, J., Ed., Light Metals, Springer, Cham, 449-456.

[3] Oudot, M., Cassayre, L., Chamelot, P., Gibilaro, M., Massot, L., Pijolat, M. and Bouvet, S. (2014) Layer Growth Mechanisms on Metallic Electrodes under Anodic Polarization in Cryolite-Alumina Melt. Corrosion Science, 79, 159-168.

[4] Helle, S., Pedron, M., Assouli, B., Davis, B., Guay, D. and Roué, L. (2010) Structure and High-Temperature Oxidation Behaviour of $\mathrm{Cu}-\mathrm{Ni}$-Fe Based Alloys Prepared by High-Energy Ball Milling for Application as Inert Anodes Fort Aluminum Electrolysis. Corrosion Science, 52, 3348-3355. https://doi.org/10.1016/j.corsci.2010.06.011

[5] Gallino, I., Kassner, M.E. and Busch, R. (2012) Oxidation and Corrosion of Highly Alloyed $\mathrm{Cu}-\mathrm{Fe}-\mathrm{Ni}$ as Inert Anode Material for Aluminum Electrowinning in as-Cast and Homogenized Conditions. Corrosion Science, 63, 293-303. https://doi.org/10.1016/j.corsci.2012.06.013

[6] Olsen, E. and Thonstad, J. (1999) Nickel Ferrite as Inert Anode in Aluminium Electrolysis: Part II-Material Performance and Long-Term Testing and Preliminary Testing. Journal of Applied Electrochemistry, 29, 301-311. https://doi.org/10.1023/A:1003464304488

[7] Zarrabian, P., Kalantar, M. and Ghasemi, S.S. (2014) Fabrication and Characterization of Nickel Ferrite Based Inert Anodes for Aluminum Electrolysis. Journal of Material Engineering Performance, 23, 1656-1664. https://doi.org/10.1007/s11665-014-0914-y

[8] Pawlek, R.P. (2014) Inert Anodes: An Update. In: Grandfield, J., Ed., Light Metals, Springer, Cham, 1309-1313.

https://doi.org/10.1007/978-3-319-48144-9 219

[9] Tian, Z.L., Lai, Y.Q., Li, J., Li, Z.Y., Zhou, K.C. and Liu, Y.X. (2008) Effect of Cu-Ni content on the Corrosion Resistance of $(\mathrm{Cu}-\mathrm{Ni}) /\left(10 \mathrm{NiO}-90 \mathrm{NiFe}_{2} \mathrm{O}_{4}\right)$ Cermet Inert Anode for Aluminum Electrolysis. Acta Metallurgica Sinica, 21, 72-78. https://doi.org/10.1016/S1006-7191(08)60022-8

[10] Ray, S.P. (1980) Composition for Inert Electrodes, Aluminum Company of America. US Patent No. 4399008.

[11] Ray, S.P. (1980) Inert Electrode Formulation, Aluminum Company of America. US Patent No. 4374761.

[12] Tarcy, G.P. (1986) Corrosion and Passivation of Cermet Inert Anodes in Cryolite-Type Electrolytes. In: Grandfield, J., Ed., Light Metals, Springer, Cham, 309-320.

[13] Weyand, J.D., Deyoung, D.H., Ray, S.P., Tarcy, G.P. and Baker, F.W. (1985) Inert 
Anodes for Aluminium Smelting. Aluminium Company of America, Final Report.

[14] Lai, Y.Q., Tian, Z.L., Li, J., Ye, S.L. and Liu, Y.X. (2006) Preliminary Testing of $\mathrm{NiFe}_{2} \mathrm{O}_{4}-\mathrm{NiO}-\mathrm{Ni}$ Cermet as Inert Anode in $\mathrm{Na}_{3} \mathrm{AlF}_{6}-\mathrm{AlF}_{3}$ Melts. Transactions of Nonferrous Metals Society of China, 16, 654-658. https://doi.org/10.1016/S1003-6326(06)60116-7

[15] Tian, Z.L., Lai, Y.Q., Li, J. and Liu, Y.X. (2008) Effect of Ni Content on Corrosion Behaviour of $\mathrm{Ni} / 10 \mathrm{NiO}-90 \mathrm{NiFe}_{2} \mathrm{O}_{4}$ ) Cermet Inert Anode. Transactions of Nonferrous Metals Society of China, 18, 361-365. https://doi.org/10.1016/S1003-6326(08)60063-1

[16] Liu, J.Y., Li, Z.Y., Tao, Y.Q., Zhang, D. and Zhou, K.C. (2011) Phase Evolution of $17(\mathrm{Cu}-10 \mathrm{Ni})-\left(\mathrm{NiFe}_{2} \mathrm{O}_{4}-10 \mathrm{NiO}\right)$ Cermet Inert Anode during Aluminum Electrolysis. Transactions of Nonferrous Metals Society of China, 21, 566-572. https://doi.org/10.1016/S1003-6326(11)60752-8

[17] He, H.B., Wang, Y., Long, J.J. and Chen, Z.H. (2013) Corrosion of $\mathrm{NiFe}_{2} \mathrm{O}_{4}-10 \mathrm{NiO}$-Based Cermet Inert Anodes for Aluminium Electrolysis. Transactions of Nonferrous Metals Society of China, 23, 3816-3821. https://doi.org/10.1016/S1003-6326(13)62934-9

[18] Tian, Z., Lai, Y., Yang, S., Li, J., Hwang, J.Y. and Liu, Y. (2015) Anodic Corrosion Behavior of $\mathrm{NiFe}_{2} \mathrm{O}_{4}$-Based Cermet in $\mathrm{Na}_{3} \mathrm{AlF}_{6}-\mathrm{K}_{3} \mathrm{AlF}_{6}-\mathrm{AlF}_{3}$ for Aluminum Production. Metallurgical and Materials Transactions B, 46, 1257-1261. https://doi.org/10.1007/s11663-015-0328-8

[19] Meyer, P., Gibilaro, M., Massot, L., Pasquet, I., Tailhades, P., Bouvet, S., Chamelot, P. (2018) Influence of Ni Content on $\mathrm{Ni}_{\mathrm{x}} \mathrm{Fe}_{3-\mathrm{x}} \mathrm{O}_{4}$ Spinel Chemical Stability in Molten Fluorides. Materials Science and Engineering B, 228, 117-122. https://doi.org/10.1016/j.mseb.2017.11.025

[20] Chamelot, P., Lafage, B. and Taxil, P. (1996) Studies of Niobium Electrocrystallization Phenomena in Molten Fluorides. Journal of Electrochemical Society, 143, 1570-1576. https://doi.org/10.1149/1.1836681

[21] Sterten, A. (1980) Structural Entities in $\mathrm{NaF}-\mathrm{AlF}_{3}$ Melts Containing Alumina. Electrochimica Acta, 25, 1673-1677. https://doi.org/10.1016/0013-4686(80)80021-1

[22] Gilbert, E., Robert, E., Tixhon, J.E. and Ostvold, O.T. (1995) Acid-Base Properties of Cryolite Based Melts with $\mathrm{CaF}_{2}, \mathrm{MgF}_{2}$ and $\mathrm{Al}_{2} \mathrm{O}_{3}$ Additions. In: Grandfield, J., Ed., Light Metals, Springer, Cham, 181-194.

[23] Kelly, M., Zanghi, D., Salanne, M., Stabrowski, V. and Bessada, C. (2018) Anionic Structure in Molten Cryolite-Alumina Systems. Journal of Physical Chemistry, 122, 21807-21816. https://doi.org/10.1021/acs.jpcc.8b06905

[24] M. Oudot, L. Cassayre, P. Chamelot, M. Gibilaro, L. Massot, M. Pijolat, S. Bouvet (2014) Layer Growth Mechanisms on Metallic Electrodes under Anodic Polarization in Cryolite-Alumina Melt. Corrosion Science, 79, 159-168. https://doi.org/10.1016/j.corsci.2013.10.040

[25] Massot, L., Cassayre, L., Chamelot, P. and Taxil, P. (2007) On the Use of Electrochemical Techniques to Monitor Free Oxide Content in Molten Fluoride Media. Journal of Electroanalytical Chemistry, 606, 17-23. https://doi.org/10.1016/j.jelechem.2007.04.005

[26] Cassayre, L., Chamelot, P., Arurault, L., Massot, L. and Taxil, P. (2008) Oxidation of Stoichiometric Nickel Ferrites Used as Inert Anodes for Aluminium Electrolysis in Molten Cryolite Mixtures. Materials Science Forum, 595-598, 593-600. https://doi.org/10.4028/www.scientific.net/MSF.595-598.593 
[27] Corso, S. (2004) Elaboration et caractérisation de céramiques à base de ferrites de nickel. Etude de leurs propriétés en vue de la conception d'anodes inertes de type oxydes ou cermets destinées à l'électrolyse de l'aluminium, $\mathrm{PhD}$ Thesis, Université Paul Sabatier Toulouse.

[28] Morin, F.J. (1954) Electrical Properties of NiO. Physical Review Journals Archive, 93, 1199-1204. https://doi.org/10.1103/PhysRev.93.1199

[29] Lorentsen, O. (2000) Behaviour of Nickel, Iron and Copper by Application of Inert Anodes in Aluminum Production. Norwegian University of Science and Technology, Trondheim. 